\title{
A Techno-Economic Analysis of PEV Battery Second Use: Repurposed-Battery Selling Price and Commercial and Industrial End-User Value
}

\author{
Jeremy S. Neubauer and Ahmad Pesaran \\ National Renewable Energy Laboratory \\ Brett Williams \\ University of California, Berkeley \\ Mike Ferry \\ California Center for Sustainable Energy \\ Jim Eyer \\ E\&I Consulting
}

\begin{abstract}
Accelerated market penetration of plug-in electric vehicles (PEVs) is presently restricted by the high cost of batteries. Deployment of grid-connected energy storage, which could increase the reliability, efficiency, and cleanliness of the grid, is similarly inhibited by the cost of batteries. Research, development, and manufacturing are underway to reduce cost by lowering material costs, enhance process efficiencies, and increase production volumes. Another approach under consideration is to recover a fraction of the battery cost after the battery has been retired from vehicular service via reuse in other applications, where it may still have sufficient performance to meet the requirements of other energy-storage applications. By extracting additional services and revenue from the battery in a post-vehicle application, the total lifetime value of the battery is increased, thereby decreasing the overall cost of energy-storage solutions for both primary (automotive) and secondary (grid) customers. In this paper, a techno-economic analysis of second use is described, taking into consideration the effects of battery degradation in both automotive and grid service, repurposing costs, balance-ofsystems costs, the value of aggregated energy-storage to commercial and industrial end users, and competitive technology. It is shown that under our chosen assumptions the batteries from PEVs can economically be used to serve
\end{abstract}

the power quality and reliability needs of commercial and industrial end users (e.g., with system payback periods ranging from 7 to 10 years). However, the value to the automotive battery owner is small (e.g., $\$ 20-\$ 100 / \mathrm{kWh}$ ), as declining future battery costs and other factors are expected to strongly affect the selling price. We forecast repurposed automotive battery prices to range from approximately $\$ 38 / \mathrm{kWh}$ to $\$ 132 / \mathrm{kWh}$.

\section{INTRODUCTION}

Accelerated market penetration of plug-in electric vehicles (PEVs) is presently restricted by the high cost of batteries. Deployment of grid-connected energy storage systems, which could increase the reliability, efficiency, and cleanliness of the grid, is similarly inhibited by the cost of batteries. Research, development, and manufacturing are underway to reduce cost by lowering material costs, enhance process efficiencies, and increase production volumes. Another approach under consideration is to recover a fraction of the battery cost after the battery has been retired from vehicular service via reuse in other applications, where it may still have sufficient performance to meet the requirements of other energy-storage applications $[\underline{1}, \underline{2}, \underline{3}, \underline{4}, \underline{5}]$. By extracting additional services and revenue from the battery in a postvehicle application, the total lifetime value of the battery is increased. Thusly, the overall cost of energy-storage solutions 
for both the primary (automotive) and secondary (grid) customer could be decreased.

The U.S. Department of Energy's (DOE's) Vehicle Technologies Program has funded the National Renewable Energy Laboratory (NREL) to answer these questions and investigate the second use of modern lithium-ion PEV batteries in grid-related applications. In partnership with a multi-disciplinary team led by the California Center for Sustainable Energy, NREL conducted a techno-economic analysis of battery second use to help answer these questions and guide future research. This paper presents a subset of that analysis, which considers the effects of battery degradation in both automotive and grid service, repurposing costs, balanceof-systems costs, the value of aggregated energy storage to commercial and industrial end users, and competitive technology to assess the economic viability of battery seconduse strategies.

\section{ANALYSIS}

Herein we estimate the value of used PEV batteries by first calculating a maximum allowable value for the repurposedbattery selling price by requiring that repurposed batteries be cost competitive with equally capable new batteries. Next we compute the cost of repurposing used automotive batteries and explore its dependence on the size of the pack or module being repurposed using a detailed economic model of a repurposing facility. Subtracting the cost of repurposing from the repurposed-battery selling price yields the maximum achievable used-battery buying price. Finally, we compute the system cost and value of an energy-storage system utilizing repurposed PEV batteries to provide power quality, power reliability, time-of-use (TOU) charge management, and demand-charge (DC) management services to a commercial or industrial end user.

\section{REPURPOSED-BATTERY SELLING PRICE}

We begin the calculation of future repurposed-battery selling prices by assuming the principal competitor for used PEV batteries in second-use applications is newly produced PEV batteries, and that demand will exist for used batteries priced less than equally capable new batteries is valid. Thus the future selling price of a repurposed PEV battery will be proportional to the cost of a new battery $\left(C_{N}\right)$, taking into consideration the health of the used battery $\left(K_{h}\right)$ and a usedproduct discount factor $\left(K_{U}\right.$, equal to the ratio of what a customer is willing to pay for a used product to what that same customer is willing to pay for an equally capable new product) as shown in equation 1 . Further details of this methodology are discussed in [4] .

$$
P_{\text {repurposed battery }}=K_{U} K_{h} C_{N}
$$

The health factor is a major component of this equation. Herein we take a slightly different approach to calculating the health factor than was done in [4], applying a present-valueof-throughput (PVT) metric to compare the state of heath of a repurposed battery to a new battery. PVT is defined in equation 2. It effectively accounts for the present value of both the capacity and cycle life of the battery, assuming a discount rate associated with the time value of money of $10 \%$ per year and that the value of a kilowatt-hour $(\mathrm{kWh})$ of energy storage increases at a rate of $2.5 \%$ per year.

$$
P V T=\sum_{i=1}^{n} \frac{(1+0.025)^{i-0.5}}{(1+0.10)^{i-0.5}} x_{i}
$$

Where:

$$
\begin{aligned}
& i=\text { year } \\
& n=\text { battery life in years } \\
& x_{i}=\text { annual battery throughput in } \mathrm{kWh}
\end{aligned}
$$

Using this metric, we can then calculate the second-use health factor of a repurposed battery by dividing the remaining PVT of a used automotive battery by that of a new battery put to work providing the same service (equation 3 ).

$$
K_{h}=P V T_{U} / P V T_{N}
$$

Where:

$P V T_{U}=$ present value of throughput of a used battery serving a grid application after automotive use $P V T_{N}=$ present value of throughput of a new battery that will serve the same grid application throughout its entire life

To perform such a calculation, it is not only necessary to know the true state of health of the battery being removed from automotive service and the operational requirements of the grid service to be provided, but also to have the capability to accurately predict battery life under these conditions. To serve these purposes, an NREL-developed high-fidelity degradation model capable of considering complex battery duty cycles and accurately capturing the impact of depth of discharge, temperature, and state of charge is employed [6]. Herein we also restrict the maximum battery calendar life to 20 years on the assumption that automotive batteries will not be designed to substantially exceed an assumed vehicle lifetime of 15 years, and therefore other mechanisms (e.g., corrosion, failure of cell seals, fatigue of electrical connections, long-term effects not yet witnessed in the 
supporting data, etc.) not accounted for in the model may lead to pack failure by this time. Note that the 20 -year limit is applied not only as a maximum for each individual phase, but also for the combination of automotive and second-use phases. Thus, if a battery provides only 12 years of automotive service, its maximum tenure in second use is restricted to a maximum of 8 years, regardless of its predicted electrochemical performance.

To compute $P V T_{N}$, we apply this model directly to a simplified peak-shaving duty cycle relevant to DC management consisting of a constant-power, two-hour discharge in the afternoon and a six-hour, constant-power, constant-voltage charge overnight, performed 252 days per year. An average temperature of 10 degrees Celsius above the U.S. national average ambient temperature of $11.16^{\circ} \mathrm{C}$ was assumed [7]. We selected a maximum state of charge (SOC) of $95 \%$ and a depth of discharge (DOD) of $60 \%$, which nearly matches the battery's electrochemical life to the imposed 20-year maximum calendar life.

To compute $P V T_{U}$, we apply the same battery degradation model in conjunction with an NREL-developed vehicle simulation tool to first calculate the automotive service life of the battery per the assumptions in Table 1 . One issue with performing this calculation is selecting a relevant drive pattern, as battery degradation is particularly sensitive to this factor. To address this point we performed this calculation on 398 vehicle-specific drive patterns attained from the Puget Sound Regional Council's 2007 Traffic Choices Study []․ We have processed the first three months of this data by first eliminating vehicles with no driving during the period of interest as well as those with significant errors in the data, and then reducing detailed trip data to daily driving distance based upon the length of each trip and the date on which it was started. The resultant 398 vehicle-specific discrete probability distribution functions of daily drive distance are employed for calculating automotive service life using the NREL vehicle simulation and battery degradation tools. These are applied to the plug-in hybrid (PHEV) and battery (BEV) electric vehicles characterized in Table 1 at beginning of life (BOL). Automotive battery lifetime is selected such that the total cost of ownership is minimized, considering the effect of reduced battery performance on electric miles traveled, the cost of replacement batteries, and the used battery buying price (assuming a $\$ 32 / \mathrm{kWh}$ repurposing $\operatorname{cost}^{1}$ and a 0.75 used-product discount factor). Following the calculation of automotive service life, the battery's remaining life serving the grid (in the manner described above for $\left.P V T_{N}\right)$ is calculated.
Table 1. PEV vehicle parameters

\begin{tabular}{lll}
\hline Drivetrain & PHEV35 & BEV75 \\
\hline Vehicle Type & Midsize Sedan & Midsize Sedan \\
All Electric Range @ BOL & 35 miles & 75 miles \\
Maximum SOC@BOL & $100 \%$ & $100 \%$ \\
Minimum SOC@BOL & $20 \%$ & $0 \%$ \\
\hline
\end{tabular}

This analysis requires knowledge of the cost of new batteries in the future to allow for cost-optimal battery replacement decisions as well as computation of total costs of ownership. Projections for future battery costs vary significantly, as shown in Figure $1[\underline{9}, \underline{10}, \underline{11}, \underline{12}, \underline{13}]$. For the moment, we restrict our investigation to a forecast based upon the Boston Consulting Group's high cost estimates in which battery prices start at $\$ 795$ per kilowatt-hour $(\$ 795 / \mathrm{kWh})$ in 2012 (the start date of our simulations), fall linearly to $\$ 440 / \mathrm{kWh}$ in 2020, and then hold steady [9].

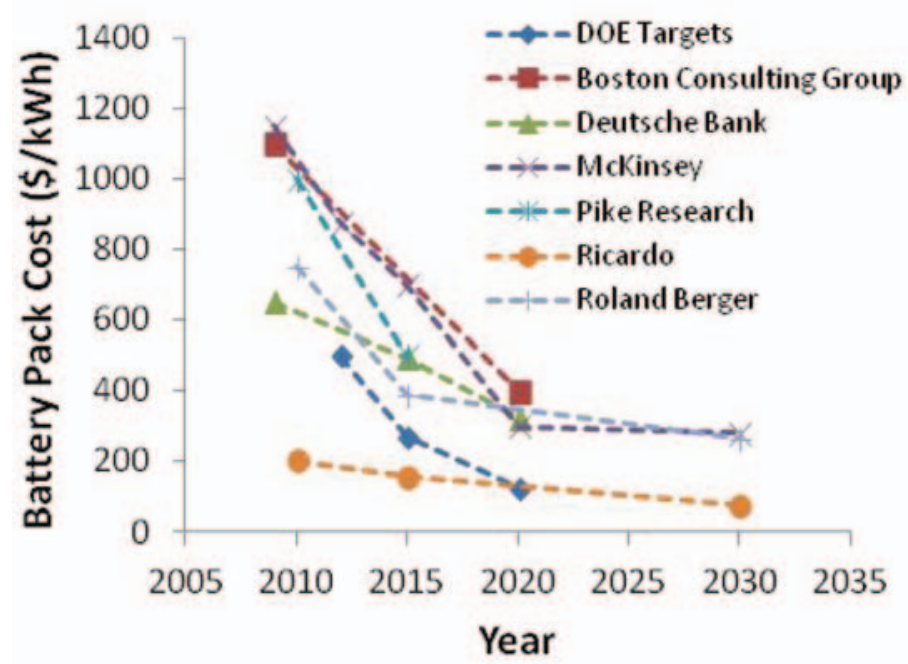

Figure 1. Li-ion automotive battery cost projections and targets

Figure 2 shows the spectrum of second-use battery health factors for the simulated BEV and PHEV. These data are based upon the 99 most cost-effective drive patterns for each scenario as computed using NREL's Battery Ownership Model [14], which are presumed to represent over time the most likely drive patterns to utilize PEVs and yield used batteries. For this subset we found that battery replacement was never financially justified, and thus the battery always lasted the 15-year life of the vehicle. As seen in Figure 2, second-use battery lifetime and health factor varied for the BEV, but nearly half of cases were limited by the imposed 20 -year maximum calendar lifetime, resulting in a second-use lifetime of 5 years and a $40 \%$ health factor. The PHEV, on

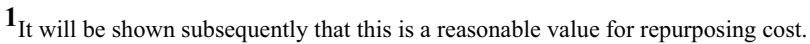




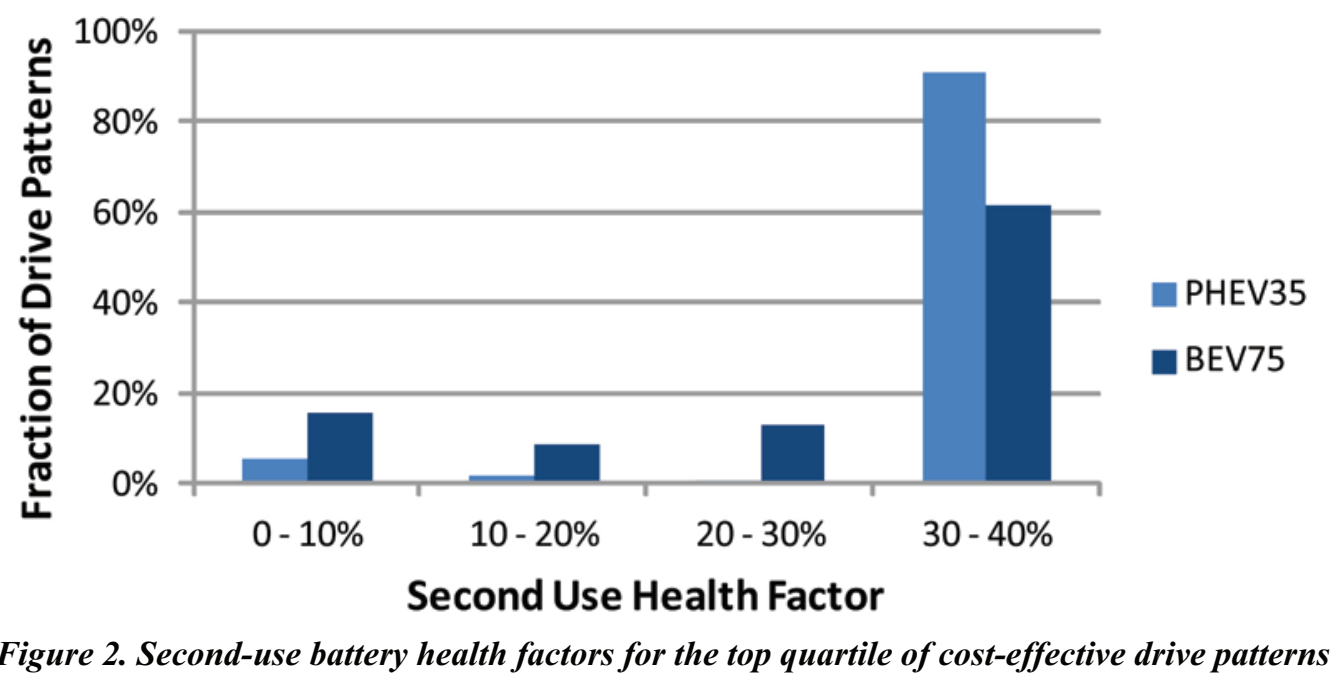

the other hand, was found to be bound by the 20-year calendar limit $90 \%$ of the time.

Based on these results, the rest of this analysis assumes a 15year automotive life time, a 5-year second-use lifetime, and a $40 \%$ health factor for both used BEV and PHEV batteries. Combining these values with an assumed used-product discount factor of 0.75 produces a repurposed-battery sale price of $\$ 132 / \mathrm{kWh}$. Note that this result is highly sensitive to future battery prices-if future battery prices fall to the DOE's 2020 target value of $\$ 125 / \mathrm{kWh}$, the repurposed-battery sale price falls to $\$ 38 / \mathrm{kWh}$. As these numbers are based on the BOL battery energy, they may be compared directly with BOL battery prices.

\section{USED-BATTERY BUYING PRICE \& REPURPOSING COST}

Knowing the repurposed-battery selling price, we can identify the used-battery buying price paid to the automotive battery owner only if we can calculate the costs involved in the processes between retiring a battery from automotive service and selling it to a secondary market (collection, testing, repackaging, warranty, etc.), herein referred to as repurposing costs. Cready et al. estimated these costs at $\$ 65.27 / \mathrm{kWh}$ in 2002 using a bottom-up approach that considered all labor, capital equipment, facility needs, required rate of return by the operating entity, and many other factors [1]. In this study, we update that analysis to address the needs and capabilities of modern battery hardware and to explore the effect of module size on repurposing costs. The most significant changes we make to [1] are a reduction in the amount of electrical testing time and the elimination of pack assembly costs. The former assumes access to sophisticated onboard diagnostics data, and the latter is based on the assumption that the repurposing facility will ship the same size module it receives, leaving integration of multiple modules into larger systems to the energy-storage systems integrator ${ }^{2}$. These omitted systems integration costs will be addressed in the end-user cost section below.

Our revised assumptions and connections between values are detailed in Tables $2, \underline{3}, \underline{4}, \underline{5}, \underline{6}$. Once a module size is set, then all of the facility, capital, labor, and other costs can be calculated based on a constant annual throughput of 115,920 $\mathrm{kWh}$ (selected to achieve approximate parity between our scenarios and [1]. on the total $\mathrm{kWh}$ of batteries on-site at the repurposing facility) over 252 days of facility operation. Next, we compute the facility's module yield based on the likelihood that a bad cell is present within a module purchased by the repurposing facility. To do this, we specify a cell fault rate of $1 \%, 0.1 \%$, or $0.01 \%$, representative of the chance that a purchased cell is bad. To translate this to a module level yield, we assume a common cell size of $74 \mathrm{Wh}$ (approximately $20 \mathrm{Ah}$ at $3.7 \mathrm{~V}$ nominal) and apply equation $\underline{4}$. Finally, the required battery selling price (in $\$ / \mathrm{kWh}$ ) is calculated to provide a five-year payback period given an internal rate of return of $10 \%$ and effective corporate tax rate of $39.3 \%$ [15]. The effective repurposing cost is then found by subtracting the buy price from the $\$ 132 / \mathrm{kWh}$ selling price. The results of this analysis across module sizes ranging from 1 to $24 \mathrm{kWh}$ for the three selected cell fault rates are shown in Figure 3 and $\underline{4}$.

$$
\text { Module Yield }=(\text { Cell Fault Rate })^{\text {Module Size/74Wh }}
$$

It should be noted that we do not make special consideration for the impact of the classification of used Li-ion batteries as hazardous waste. Narula et al. [16] highlight correctly that the

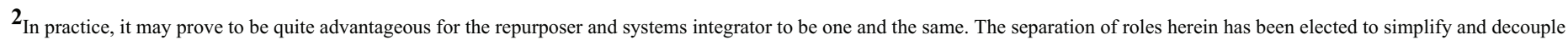
the math of these operations to maintain flexibility within the scope of our analysis.
} 
Table 2. Module repurposing time requirements

\begin{tabular}{lll}
\hline Operation & Required Time & Reference / Notes \\
\hline Receiving Inspection & 60 minutes & \\
Connection to Electrical Test Equipment & 20 minutes & Allows for a full charge and \\
Electrical Test Time & 240 minutes & discharge at 1C with rests \\
Disconnection from Electrical Test Equipment & 10 minutes & \\
Final Inspection and Packaging & 30 minutes & \\
\hline
\end{tabular}

Table 3. Module repurposing facility

\begin{tabular}{|c|c|c|}
\hline Description & Value & Reference / Notes \\
\hline Average Daily Battery Throughput & $460 \mathrm{kWh}$ & $\begin{array}{l}\text { Calculated to achieve approximate parity between our } \\
\text { scenarios and that of Cready et al. on the total kWh of } \\
\text { batteries on-site at the repurposing facility }\end{array}$ \\
\hline Annual Operating Days & 252 days & \\
\hline Square Footage & $10,173 \mathrm{ft}^{2}$ & \\
\hline Rent & $\$ 0.69 / \mathrm{mo} / \mathrm{ft}^{2}$ & $\begin{array}{l}\text { LA area } \underline{\mathrm{http}: / / \text { www.grubb- }} \\
\text { ellis.com/SitePages/GetFileFromDB.ashx?type }=9 \& i d=1188\end{array}$ \\
\hline Annual Electricity - Testing & $\begin{array}{l}\$ 0.104 / \mathrm{kWh} \times 1.5 \mathrm{x} \\
\text { annual throughput }\end{array}$ & http://www.eia.gov/electricity/data.cfm\#sales \\
\hline Annual Electricity - Other & $\$ 2.25 / \mathrm{ft}^{2}$ & http://btscoredatabook.eren.doe.gov \\
\hline
\end{tabular}

Table 4. Module repurposing capital equipment

\begin{tabular}{|c|c|c|c|}
\hline Description & Quantity & Unit Cost & Reference / Notes \\
\hline Battery Test Channel & $\begin{array}{l}\text { No. of modules per day } / 4 ; \\
\text { each channel rated for a } \\
\text { maximum } \sim 2 \mathrm{C} \text { discharge }\end{array}$ & $\$ 2,000 / \mathrm{kW}$ & $\begin{array}{l}\text { Although } 1 \mathrm{C} \text { average discharge and } \\
\text { charge rates are assumed, } 2 \mathrm{C} \text { pulses } \\
\text { may be needed for resistance } \\
\text { characterization }\end{array}$ \\
\hline Battery Test Channel 4x Multiplexer & 1 per battery test channel & $\$ 2,000$ ea. & $\begin{array}{l}\text { Allows four batteries to be connected } \\
\text { to a single test channel and tested } \\
\text { sequentially without manual } \\
\text { interaction. }\end{array}$ \\
\hline Controller Area Network & 1 per battery test channel & $\$ 160$ ea. & \\
\hline Communication Hardware & & & \\
\hline Computers & No. of battery test channels / 4 & $\$ 3,000$ ea. & \\
\hline Storage Racks & 1 & $\$ 6,280$ ea. & \\
\hline Forklift & 1 & $\$ 22,537$ ea. & \\
\hline Delivery Truck & 1 & $\$ 70,000$ ea. & \\
\hline Office \& Other Equipment & 1 & $\$ 100,000$ ea. & \\
\hline
\end{tabular}

amount of lithium in PEV batteries is sufficient for them to be categorized as class 9 hazardous materials under Code of Federal Regulations Title 49, Part 173.185 (49 CFR 173.185), and as such need to be shipped following certain guidelines (e.g., packaged in rigid containers and in a manner to effectively prevent short circuits, violent rupture, etc.). The authors state, "As hazardous materials, used batteries can be transported from dealer to refurbishing factory by truck, and the driver can be an employee of the refurbishing company,"
$[16$, p. $2-8]$. We adopt this assumption in our calculations here, accounting only for minimal additional shipping preparations as required by $49 \mathrm{CFR} 173.185^{3}$.

Several important trends are revealed in the results of this analysis shown in Figures 3 and $\underline{4}$. First is the extremely poor module yield that results from a $1 \%$ cell fault rate. Even an order of magnitude lower $0.1 \%$ cell fault rate produces poor module yield rates $(<80 \%)$ as the module size moves towards

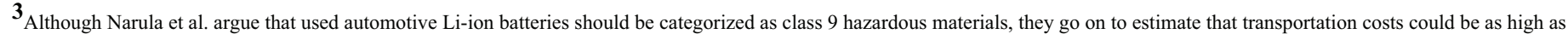

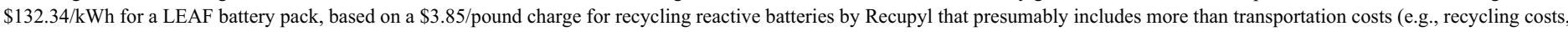
recycling profit margins, etc.), assuming the materials recovered do not yet pay for these elements. [For comparison, an identical \$3.85/lb quote on an AERC price sheet (http://

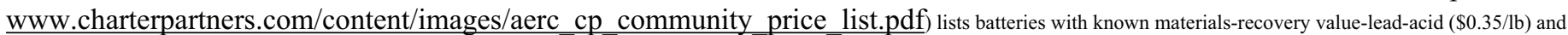

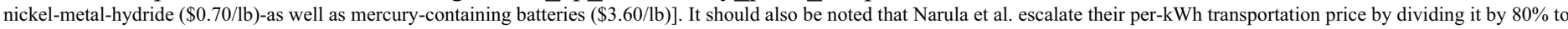

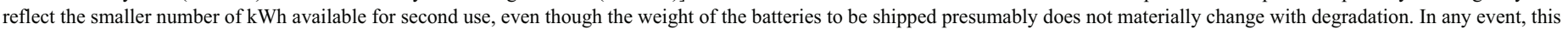
result makes second-use strategies financially impractical and thus will not be considered herein.
} 
Table 5. Module repurposing labor

\begin{tabular}{|c|c|c|c|}
\hline Description & Quantity & Annual Wage & Reference / Notes \\
\hline Test Technician & $\begin{array}{l}1 \text { per battery test channel, } \\
\text { rounded up }\end{array}$ & $\$ 35,550$ ea. & BLS Occupation Code 51-9061 \\
\hline Supervisors & $\begin{array}{l}\text { No. of Test Technicians / 10, } \\
\text { rounded down }\end{array}$ & $\$ 56,170$ ea. & BLS Occupation Code 51-1011 \\
\hline Forklift Driver & 1 & $\$ 31,500$ ea. & BLS Occupation Code 53-7051 \\
\hline Truck Driver & 1 & $\$ 32,140$ ea. & BLS Occupation Code 53-3033 \\
\hline Administrative Assistant & 1 & $\$ 32,000$ ea. & BLS Occupation Code 43-6014 \\
\hline Electrical Engineer & 1 & $\$ 87,770$ ea. & BLS Occupation Code 17-2071 \\
\hline Sales Manager & 1 & $\$ 114,110$ ea. & BLS Occupation Code 11-2022 \\
\hline Operations Manager & 1 & $\$ 113,100$ ea & BLS Occupation Code 11-1021 \\
\hline Chief Executive & 1 & $\$ 173,350$ ea & BLS Occupation Code 11-1011 \\
\hline
\end{tabular}

http://www.bls.gov/oes/current/oes_nat.htm\#17-0000

Table 6. Module repurposing - other annual costs

\begin{tabular}{llll}
\hline Description & Quantity & Unit Cost & Reference / Notes \\
\hline \hline Transportation & $30,000 \mathrm{mi}$ & $\$ 0.375 / \mathrm{mi}$ & \\
Insurance & $3 \%$ of direct costs & & \\
General \& Administrative & $5 \%$ of direct costs & & \\
Warranty & $5 \%$ of battery sales & & http://www.bls.gov/news.release/ecec.nr0.htm \\
Non-Wage Labor & $29.6 \%$ of labor costs & & \\
Used Batteries & $115,920 \mathrm{kWh}$ & $\$ 132 / \mathrm{kWh}$ & \\
\hline
\end{tabular}

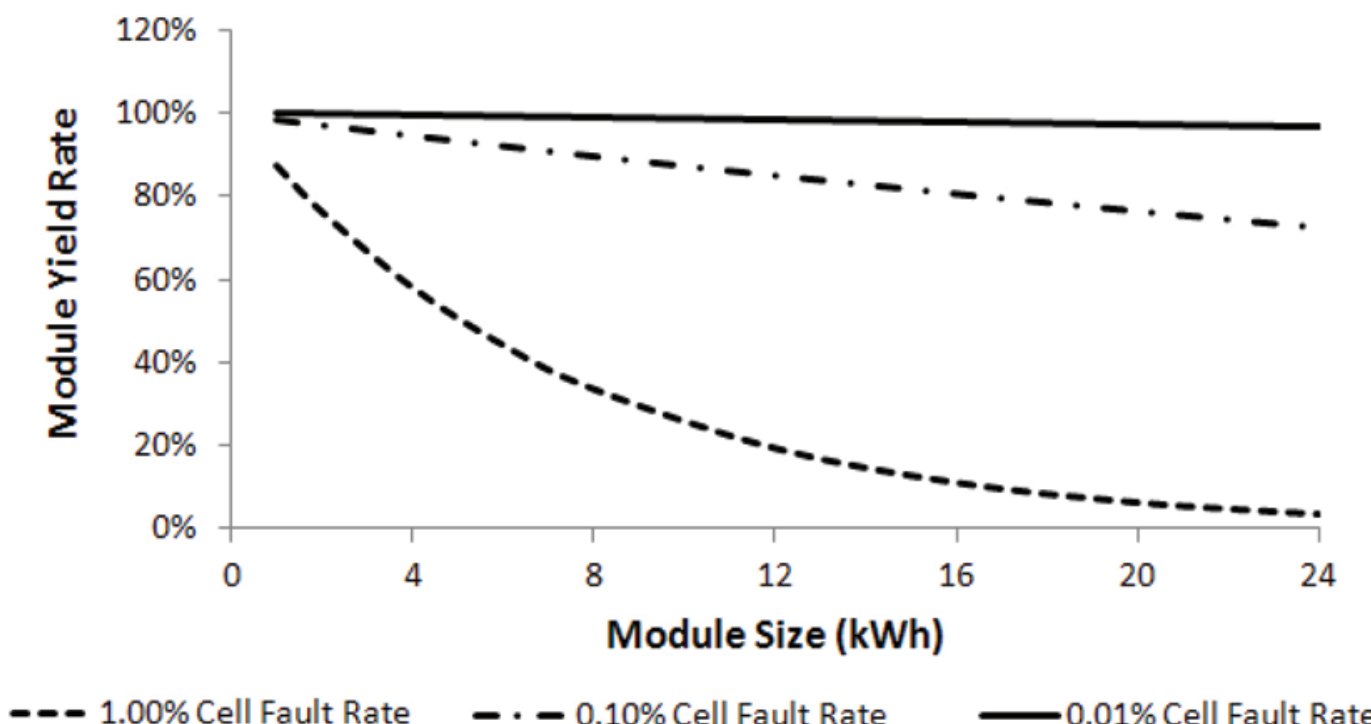

Figure 3. Repurposed module yield rate as a function of module size and cell fault rate

full BEV pack sizes $(>16 \mathrm{kWh})$. Second is how the combination of module yield rates and labor costs affect optimal module size for repurposing. When cell fault rates are extremely low $(0.01 \%)$, the module yield is $>97 \%$ for all module sizes considered herein. Thus, with low fault rates, the impact of module size on the economics is minimal, leaving the lower per-kWh labor costs of handling larger modules to drive total repurposing cost. However, as cell fault rates increase, we find an increasingly lower optimal module size: at a cell fault rate of $0.1 \%$ it is found that repurposing $6-\mathrm{kWh}$ modules minimizes costs, while at a cell fault rate of $1 \%$ repurposing $2-\mathrm{kWh}$ modules is cost-optimal. Finally, we notice a strong overall sensitivity of repurposing cost to cell fault rate after module size has been optimally selected: the minimum repurposing cost at $0.01 \%$ cell fault rate is $25 \%$ less than that at $0.10 \%$. 


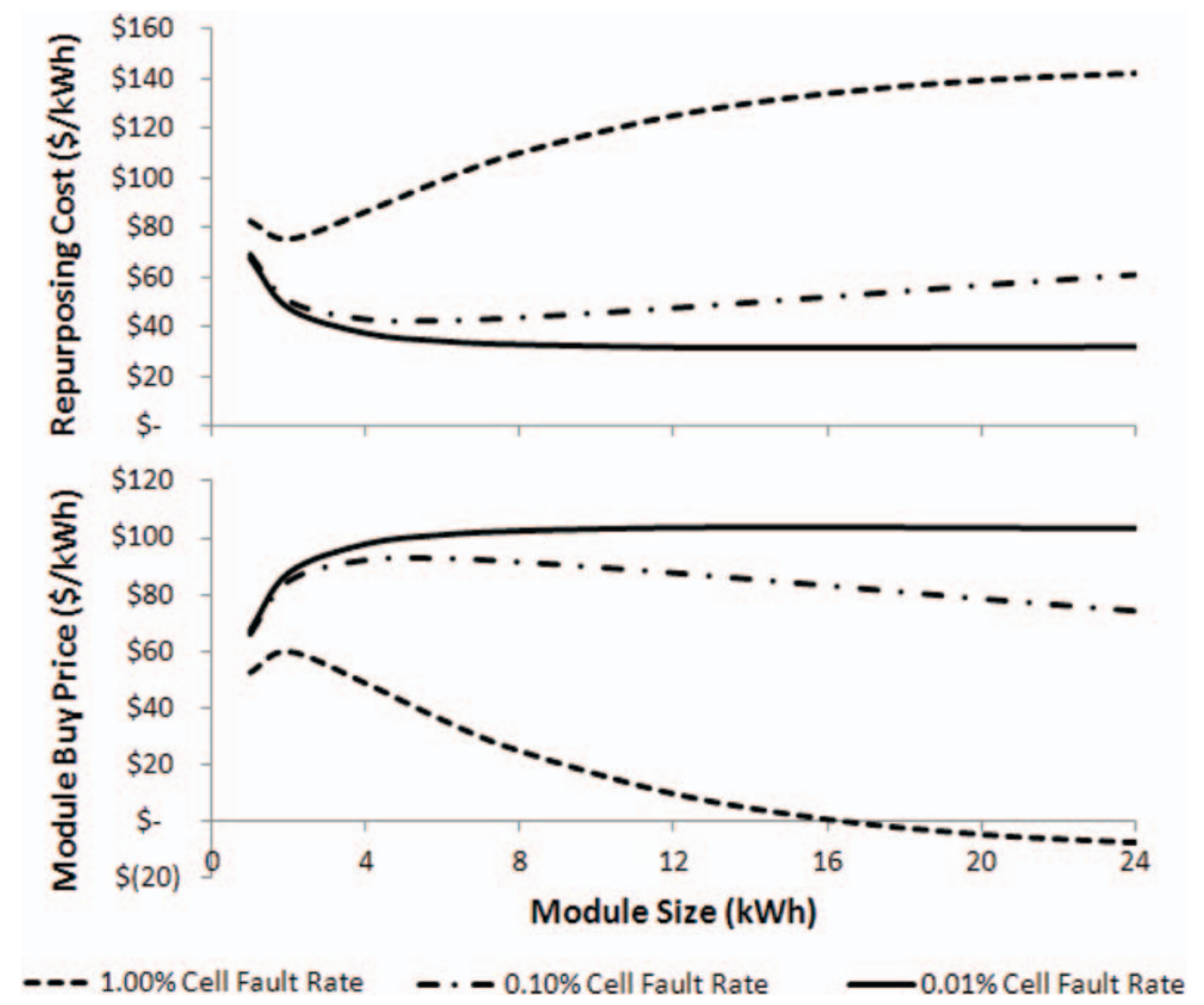

Figure 4. Repurposing cost and required module buy price as a function of module size and cell fault rate for a repurposed battery selling price of $\$ 132 / \mathrm{kWh}$

Lowering the repurposed-battery selling price to $\$ 38 / \mathrm{kWh}$ shows similar trends, though with lower overall repurposing costs and battery buying prices. Buying prices fall so much, however, that at a cell fault rate of $1 \%$, the battery buy price is negative for all module sizes, implying that the owner of the battery would have to pay $\$ 10$ to $\$ 40 / \mathrm{kWh}$ for it to be repurposed (which would only be viable if disposal or recycling is more expensive). For the other cell fault rates, battery buy prices generally vary from $\$ 10$ to $\$ 20 / \mathrm{kWh}$.

On the basis of these findings and the expectation that onboard or automotive service center diagnostics will be able to accurately identify faulty individual cells at the end of a battery's automotive service life (i.e., adopting the $0.01 \%$ cell fault rate), we proceed herein on the assumption that only full packs thought not to contain faulty cells will be repurposed. In addition to minimizing overall repurposing costs as calculated above, the repurposing of full battery packs presents the opportunity to minimize disassembly costs (which have not been considered herein), minimize integration costs for larger systems, and allow use of the original thermal and battery management systems. However, we note that these points and others need to be considered in detail prior to making the claim that the repurposing of full packs will be preferred over repurposing individual modules in practice.

Under these conditions and our high future battery cost scenario, we calculate that repurposing costs and battery buy prices will be approximately $\$ 32 / \mathrm{kWh}$ and $\$ 100 / \mathrm{kWh}$, respectively, for repurposed packs ranging from 8 to $24 \mathrm{kWh}$. Discounting the buy price back to the initial point of purchase of the PEV is indicative of the maximum effect second-use strategies can have on the upfront cost of a PEV. Assuming a discount rate of $10 \%$ over a 15 -year automotive service life, this makes for a maximum point-of-purchase discount of $\$ 22 /$ $\mathrm{kWh}$. For a typical BEV75, this translates to less than $\$ 600$ in total upfront value. As with the repurposed-battery selling price, however, all of these values are sensitive to the future cost of new batteries. Table 7 summarizes the costs and value developed in this section alongside the same values given the achievement of the DOE's 2020 target for battery cost.

It is important to note that the results so far have been driven by a price developed relative to a competing energy-storage technology (new PEV-type Li-ion batteries), and are only valid if sufficiently large demand exists for repurposed PEV batteries at the calculated selling price. 
Table 7. Summary of competitive-technology-driven second-use value

\begin{tabular}{lll}
\hline \hline Parameter & Case 1 & Case 2 \\
\hline \hline Maximum total battery lifetime & 15 years & 15 years \\
Battery health factor & $40 \%$ & $40 \%$ \\
Future new battery cost & $\$ 440 / \mathrm{kWh}$ & $\$ 125 / \mathrm{kWh}$ \\
Repurposed-battery selling price & $\$ 132 / \mathrm{kWh}$ & $\$ 38 / \mathrm{kWh}$ \\
Repurposing cost & $\$ 32 / \mathrm{kWh}$ & $\$ 18 / \mathrm{kWh}$ \\
Used-battery buying price & $\$ 100 / \mathrm{kWh}$ & $\$ 20 / \mathrm{kWh}$ \\
\hline
\end{tabular}

Table 8. End-user system cost elements

\begin{tabular}{|c|c|c|c|c|}
\hline Item & Low & Estimate & High & Comments \\
\hline \multicolumn{5}{|l|}{ Capital costs (installed) } \\
\hline $\begin{array}{l}\text { Repurposed-battery selling price } \\
(/ \mathrm{kWh} \mathrm{BOL})\end{array}$ & $\$ 38$ & $\$ 132$ & $\$ 147$ & $\begin{array}{l}\$ 147=\text { StatPack [1]. } \$ 132 \text { from } \$ 440 / \mathrm{kWh} \text { new, } \$ 38 \text { from } \\
\$ 125 / \mathrm{kWh} \text { new (above). }\end{array}$ \\
\hline $\begin{array}{l}\text { Power conditioning, controls, interfaces } \\
(/ \mathrm{kW})\end{array}$ & $\$ 100$ & $\$ 319$ & $\$ 319$ & $\begin{array}{l}\$ 319=\text { Vernon facility, } \$ 100=\text { residential load following [1]. } \\
\$ 100=\text { DOE EERE SETP goal for } 2020 \text {. }\end{array}$ \\
\hline $\begin{array}{l}\text { Accessories, facilities, shipping } \\
(/ \mathrm{kWh} \mathrm{BOL})\end{array}$ & $\$ 117$ & $\$ 117$ & $\$ 482$ & $\$ 482=$ Vernon facility, $\$ 117=$ Chino facility [1]. \\
\hline Installation and startup $(/ \mathrm{kWh} \mathrm{BOL})$ & $\$ 52$ & $\$ 52$ & $\$ 90$ & $\$ 90=$ Vernon facility, $\$ 52=$ Chino facility $[1]$. \\
\hline Recurring costs & & & & \\
\hline Operation \& maintenance $(/ \mathrm{kW}-\mathrm{y})$ & $\$ 5$ & $\$ 29$ & $\$ 58$ & $\$ 58=$ Vernon facility, $\$ 29=$ Chino facility $[1] . \$ 5=$ low $[16]$ \\
\hline $\begin{array}{l}\text { Annual insurance, property tax ( } \% \text { of } \\
\text { capital costs) }\end{array}$ & $1.0 \%$ & $1.5 \%$ & $2.0 \%$ & $1.5 \%[17]$. \\
\hline $\begin{array}{l}\text { Installation for replacement batteries } \\
\text { every } 5 \mathrm{y}(/ \mathrm{kWh} \mathrm{BOL})\end{array}$ & $\$ 4$ & $\$ 10$ & $\$ 17$ & 1 to $4 \mathrm{hrs}$ of labor at $\$ 100 / \mathrm{hr}$ to replace a LEAF-sized battery. \\
\hline
\end{tabular}

\section{END-USER ENERGY-STORAGE SYSTEM COST}

Table 8 summarizes the base cost structure for an end-user energy-storage product. Added to the repurposed-battery selling price derived above are various recurring costs and several major components based on highly capable energystorage facilities serving related applications summarized in [1]: a Vernon, CA facility providing reliability, renewables firming, peak shaving, and light commercial load following; a Puerto Rico Electric Power Authority facility providing regulation, transmission support, and spinning reserve; and a Chino, CA facility providing load leveling, energy time-shift, and transmission deferral. The "estimate" values are used for most of the calculations herein and have been selected to best represent the authors' expectations of the costs of an approximately $200-\mathrm{kW}$ energy-storage system installed and operated at a commercial or industrial facility. The "low" and "high" costs provide context for future sensitivity and uncertainty analyses.

\section{END-USER APPLICATION VALUE: POWER QUALITY AND RELIABILITY AND MINIMIZATION OF ENERGY AND DEMAND CHARGES}

Multiple studies on the value of utility-based energy-storage applications have recently been released $[\underline{1}, \underline{4}, \underline{5}, \underline{17}, \underline{18}]$. In [4] and [5] we leveraged the work of [18] to calculate the maximum revenue achievable on a dollars-per-kilowatt-hour basis for used PEV batteries serving utility applications over a range of feasible discharge durations, rates, and DODs. The results of these analyses suggest that electric service power quality and reliability (Q\&R) are two of the most valuable applications. In this study we build on the results in [4] and [5] by taking a more detailed look at computing the economic viability of these applications in a behind-the-meter commercial and/or industrial setting, while also considering the aggregation of these services with the minimization of demand and TOU charges.

We compare the economics of each scenario on a presentvalue basis, where a discount rate of $10 \%$ and escalation rate of $2.5 \%$ are applied to all costs and revenues, consistent with [18]. Battery lifetime and cost are specific to our benchmark scenario as described in Table 7. For the purpose of computing payback periods, retired automotive batteries are purchased as required until a 15-year second-use project duration is completed.

\section{Power Quality and Reliability Operation}

Taking the individual power Q\&R values from [18] and [17], we aggregate them into a single application due to their similarities and on the assumption that the power demanded for quality will be the same as that for reliability (e.g., the size of a critical load or the complete facility). Representative power requirements for reliability range from $0.2 \mathrm{~kW}$ for under-desk Uninterruptable Power Systems (UPSs) up to 10 megawatts (MW) for complete commercial and/or industrial 
facilities [18], and 50-200 kW for Li-ion systems specifically [17]. Though much larger Li-ion systems are being demonstrated for various purposes, a $200-\mathrm{kW}$ system is examined here and expected to cover events amounting to fewer than 50 each annually for quality and reliability purposes [17] (or possibly even fewer, e.g., five for reliability and ten for quality [18]). Total system energy will be varied but restricted to a minimum of $100 \mathrm{kWh} \mathrm{BOL}^{4}$. This restricts the maximum power-to-energy ratio to $2: 1$ based on $\mathrm{BOL}$ rating.

Power quality events are considered to typically last between 10 seconds and one minute [18]. The energy requirements for quality are therefore ignored and the energy capacity of the system for these applications is based on reliability needs. The reliability discharge is set to 15 minutes to allow a smooth transition to backup generation or an orderly shutdown of load, analogous to the service provided by the 14-minute-or-less UPSs analyzed in [18]. Our minimum energy requirement combined with this 15-minute duration implies that the maximum $\mathrm{DOD}^{5}$ used for Q\&R service is $50 \%$.

The annual quality benefit value calculated based on [1] $]$ and [17] ranges from $\$ 50$ per kilowatt per year $(\$ 50 / \mathrm{kW}-\mathrm{yr})$ to $\$ 375 / \mathrm{kW}-\mathrm{yr}$, and the annual reliability benefit ranges $\$ 50$ $\$ 353 / \mathrm{kW}$-yr. The combined Q\&R value could therefore range from as little as $\$ 50 / \mathrm{kW}-\mathrm{yr}$, if quality and reliability events overlapped, up to as much as the sum of the individual maxima (e.g., $\$ 728 / \mathrm{kW}-\mathrm{yr}$ ) if each event occurred discretely and its mitigation were highly valued by a single end-user. However, the combined benefit of a 15-minute system resembles the capabilities of the 14-minute-or-less UPSs analyzed in [18], which cost the equivalent of $\$ 136 / \mathrm{kW}-\mathrm{yr}$, on average. This sets a reasonable proxy for a similar system's Q\&R value, and corresponds to approximately $\$ 27,000$ per year for the $200-\mathrm{kW}, 15$-year system considered here.

\section{Time-of-Use and Demand Charge Management}

To calculate the benefit of demand and TOU charge minimization, it is necessary to know the applicable utility rate structure. For this we assume Southern California Edison's TOU-GS-3-SOP rate structure [19] as detailed in Table 9-a most favorable rate schedule for energy storage. Although it may not be widely applicable today, it is possible that similar structures will proliferate before significant numbers of retired automotive batteries become available 15 years from now as more distributed, intermittent generation is added to the grid. When DCs are countered perfectly by energy storage, the assumptions herein lead to a maximum annual benefit of approximately $\$ 37,000$ per year. TOU savings based on TOU-GS-3-SOP are relatively modest and calculated assuming that all energy capacity not serving Q\&R purposes is used daily to shift consumption to off-peak rates on 252 days out of the year. Recall that our assumed seconduse battery life is limited not by the number of remaining cycles but rather the calendar life of the module (and thus there is no additional "cost" of increased cycling). TOU revenues are reduced to account for round-trip efficiency losses $(15 \%$ at $\$ 0.05 / \mathrm{kWh})$.

Table 9. Southern California Edison's TOU-GS-3-SOP rate structure

\begin{tabular}{ll}
\hline \hline Parameter & Value \\
\hline \hline No. of Summer Months & $3 / \mathrm{yr}$ \\
Facility Related Demand Charge & $\$ 9.83 / \mathrm{kW}$ \\
Summer Time Related Demand Charge & $\$ 22.92 / \mathrm{kW}$ \\
Summer TOU Energy Cost Delta & $\$ 0.107 / \mathrm{kWh}$ \\
No. of Winter Months & $9 / \mathrm{yr}$ \\
Winter Time Related Demand Charge & $\$ 0.08 / \mathrm{kW} \mathrm{n/a}$ \\
Winter TOU Energy Cost Delta & $\$ 0.028 / \mathrm{kWh}$ \\
\hline
\end{tabular}

It is also necessary to characterize the facility's load curve. Countering a broad, flat peak in load during on-peak hours will be limited by the battery's available energy. Countering a narrow, steep peak in load during on-peak hours will alternatively be limited by the system's peak available power. To calculate value it is important to relate the peak power to the amount of energy deployed during a DC mitigation event. For the four-hour on-peak period of the TOU-GS-3-SOP rate structure examined, the minimum ratio of peak power to energy is 0.25 , corresponding to a perfectly flat load profile over this period. A triangular load profile with a constant rate of load increase up to its peak and back down to its starting value over the same four-hour period has a peak power-toenergy ratio of 0.5 . Herein we assume a load profile in between, corresponding to a peak power to energy ratio of $0.375^{6}$. Further, we assume that the facility's maximum load during TOU-GS-3-SOP's off-peak period is always less than the maximum load experienced during the on-peak period after the effects of the energy storage system are applied.

\section{End-User Revenue Scenarios}

For the scenarios considered below, TOU and DC management are directly aggregated, as we assume that the facility and time-related peak demand periods coincide with each other and with on-peak energy rates; thus discharges for both applications are always coincident. However, that cannot be assumed for aggregating all four applications together. Challenges arise when it is recognized that

\footnotetext{
4 In keeping with the previous sections, the BOL rating is that of the battery when new, at the beginning of automotive life.

$\mathbf{5}$ All usage of DOD in this paper is in reference to BOL nameplate battery energy.

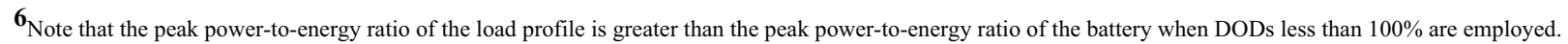


Table 10. End-user scenario system definitions

\begin{tabular}{ccccccc}
\hline Scenario & $\begin{array}{c}\text { System Power } \\
(\mathbf{k W})\end{array}$ & $\begin{array}{c}\text { System Energy } \\
\text { (kWh BOL) }\end{array}$ & $\begin{array}{c}\text { Power Q\&R } \\
\text { (\% of system } \\
\text { power) }\end{array}$ & $\begin{array}{c}\text { Q\&R DOD } \\
\text { (\%) }\end{array}$ & $\begin{array}{c}\text { DC\&TOU Power } \\
\text { (\% of system } \\
\text { power) }\end{array}$ & $\begin{array}{c}\text { DC\&TOU DOD } \\
\text { (\%) }\end{array}$ \\
\hline \hline 1 & 200 & 100 & $100 \%$ & $50 \%$ & $0 \%$ & $0 \%$ \\
\hline 2 & 200 & 200 & $100 \%$ & $25 \%$ & $13 \%$ & $35 \%$ \\
\hline 3 & 200 & 400 & $100 \%$ & $13 \%$ & $36 \%$ & $47 \%$ \\
\hline 4 & 200 & 890 & $0 \%$ & $0 \%$ & $100 \%$ & $60 \%$ \\
\hline
\end{tabular}

Table 11. End-user scenario financial results

\begin{tabular}{cccccc}
\hline \hline Scenario & Upfront Cost & 5-year Battery Replacement Cost & Annual Cost & Annual Revenue & Payback Period* \\
\hline \hline 1 & $\$ 93,900$ & $\$ 13,200$ (batteries) $+\$ 1,000$ (labor) & $\$ 7,209$ & $\$ 27,200$ \\
\hline 2 & $\$ 124,000$ & $\$ 26,400$ (batteries) $+\$ 2,000$ (labor) & $\$ 7,660$ & $\$ 7.9$ years \\
\hline 3 & $\$ 184,200$ & $\$ 52,800$ (batteries) $+\$ 4,000$ (labor) & $\$ 8,563$ & $\$ 33,607$ \\
\hline 4 & $\$ 331,690$ & $\$ 117,480$ (batteries) $+\$ 8,900$ (labor) & $\$ 10,775$ & $\$ 44,592$ & $\$ 48,879$ \\
\hline
\end{tabular}

\section{*Assumes $2.5 \% / y$ r escalation, $10 \% / y r$ discount rate}

reliability events are not predictable. For example, it may be the case that a reliability demand occurs after a DC/TOU discharge prior to the battery fully recharging. In fact, for many facilities this may be the most likely time for a reliability event (e.g., if, after considerable time at peak load, an area transformer or other grid asset fails, leaving the facility without grid power and a nearly empty battery). Further, quality, reliability, and DC revenues can fall steeply when just one discharge out of the year is missed. For example, missing a single facility load peak during a summer month can reduce total annual DC revenue by $18 \%$ under TOU-GS-3-SOP. We therefore aggregate these applications by setting aside sufficient capacity for Q\&R, and making the remainder available to reduce demand and energy charges.

To examine increasing the level of DC/TOU service, we increase the total system energy as shown in Table 10. In scenario one, we dedicate the system solely to Q\&R and set the total energy at $100 \mathrm{kWh}$ to keep the operational power-toenergy ratio at or less than $2: 1$, in order to limit concerns about thermal limitations of the battery. This results in a DOD of $50 \%$. For the second and third cases, we increase the system energy to increase the allowed amount of DC\&TOU operation. Here we set the total DOD to $60 \%$ in accordance with the life analysis results described previously. The final scenario eliminates Q\&R from consideration entirely, and increases total system energy until the full $200-\mathrm{kW}$ system power can be used for DC and TOU over a $60 \%$ DOD.

Calculated financial results for each case are shown in Table 11. All of the cases that include Q\&R show an encouraging value proposition, with payback periods ranging from 6.9 to 10.3 years. These findings partially support the use of our calculated repurposed battery price, as they demonstrate there may be a viable market for repurposed batteries at $\$ 132$ / $\mathrm{kWh}^{7}$. We find that although adding DC and TOU service to a Q\&R system increases annual revenue, it extends the payback period. This is because the upfront and recurring costs increase faster than the annual revenues as the amount of DC and TOU service is increased. When power Q\&R are removed entirely and the system is dedicated to DC and TOU, we find that the value proposition does not achieve payback within the 15-year analysis period.

Several factors could improve the argument for aggregating additional DC and TOU service, including the capture of greater TOU or DC benefits (e.g., with a different rate structure) and/or cost reductions of elements that scale with incremental additions of $\mathrm{kWh}$ capacity (e.g., repurposed battery selling price; accessories, facilities and shipping; and/or installation and startup). One particularly attractive opportunity to explore might be the integration of the energy storage system with onsite photovoltaics, which might not only allow the energy storage system to provide more photovoltaic-related value, but might create an opportunity for the two systems both to share power conditioning system costs as well as to work together to minimize DCs with minimal battery requirements and use. Another is the consideration of an increased-duration UPS product capable of riding through outages of extended length and potentially supplanting the need for backup generators, potentially providing considerably more $\mathrm{Q} \& \mathrm{R}$ value.

\section{CONCLUSIONS}

This techno-economic analysis of battery second use has considered the effects of battery degradation in both automotive and grid service, repurposing costs, competitive technology, balance-of-systems costs, and aggregating revenue streams from serving various commercial/industrial end-user needs. Having taken these factors into account, we find that new battery costs and repurposing costs are major factors affecting retired battery selling price and value to the original automotive owner. We expect repurposed automotive

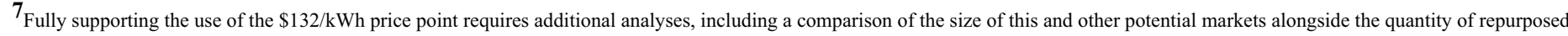
batteries expected to be available.
} 
battery prices to range from $\$ 38 / \mathrm{kWh}$ to $\$ 132 / \mathrm{kWh}$ and the value for the original battery owner (used battery buying price) to range from $\$ 20 / \mathrm{kWh}$ to $\$ 100 / \mathrm{kWh}$.

In general we find that retired automotive batteries serving as energy storage for an UPS can achieve a payback period of less than 7 years. Such products already exist and have an established market utilizing lead-acid batteries, which have been used as a basis for calculating application value. Accordingly, a payback of 7 years implies that a UPS system employing used PEV batteries has the potential to be more cost effective than today's incumbent lead acid technology. Further, repurposed PEV batteries have the potential to offer consumers superior longevity, specific energy, and energy density.

Addition of demand and TOU energy charge mitigation services were examined and found to increase the payback period even under aggressive assumptions for building load forecasting ability, profile shape, and duration, though it is noted that they can offer the opportunity to increase the total accrued revenues over the life of the system. And though not treated herein, coupling the energy-storage system with inverters already in place for photovoltaic generation systems could further improve the financial picture via shared balance-of-system costs []], more efficient offsetting of DCs, and possibly solar firming if appropriate tariffs are implemented.

\section{CONTACT INFORMATION}

Jeremy Neubauer

D.Sc. Senior Engineer

National Renewable Energy Laboratory

jeremy.neubauer@nrel.gov

Brett Williams

MPhil (cantab)

$\mathrm{PhD}$. Senior Researcher

Electric-Drive Vehicles \& Energy; Transportation Sustainability Research Center; University of California Berkeley.bdw@berkeley.edu

\section{ACKNOWLEDGMENTS}

This study was supported by Dave Howell and Brian Cunningham of the Energy Storage, Vehicle Technologies Program, Office of Energy Efficiency and Renewable Energy, U.S. Department of Energy. Special thanks to Mike Ferry and the California Center for Sustainable Energy second-use team for continued consultation and analysis of EV deployments. Thanks also to Timothy Lipman, the UC Berkeley PI and co-author on related work.

\section{DEFINITIONS/ABBREVIATIONS}

\section{BEV}

battery electric vehicle

BLS

Bureau of Labor Statistics

BOL

beginning of life

C (e.g., 1C)

C-rate of discharge

ea.

each

DC

demand charge

DOD

depth of discharge

DOE

U.S. Department of Energy

ft $^{2}$

square foot (feet)

kWh

kilowatt-hour(s)

\section{Li-ion}

lithium-ion

mo

$\operatorname{month}(\mathrm{s})$

MW

megawatt(s)

NREL

National Renewable Energy Laboratory

PEV

plug-in electric vehicle 


\section{PHEV}

plug-in hybrid electric vehicle

PVT

present value of throughput

Q\&R

quality and reliability

SOC

state of charge

TOU

time of use

UPS

uninterruptable power supply

yr

year

\section{REFERENCES}

1. Cready, E.; Lippert, J.; Pihl, J.; Weinstock, I.; Symons, P.; Jungst, R. G. Technical and Economic Feasibility of Applying Used EV Batteries in Stationary Applications: A Study for the DOE Energy Storage Systems Program; SAND2002-4084; Sandia National Laboratories: Albuquerque, NM, March, 2002.

2. Williams, B. D.; Lipman, T. E. Strategies for Transportation Electric Fuel Implementation in California: Overcoming Battery First-Cost Hurdles; CEC-500-2009-091; California Energy Commission Public Interest Energy Research (PIER) Transportation Program: Sacramento, 2009. http://www.energy.ca.gov/2009publications/ CEC-500-2009-091/CEC-500-2009-091.PDF

3. Beer, S.; Gómez, T.; Dallinger, D.; Momber, I.; Marnay, C.; Stadler, M.; Lai, J. An economic analysis of used electric vehicle batteries integrated into commercial building microgrids; Fraunhofer Institute for Systems and Innovation Research: October, 2011. http://www.mendeley.com/ research/economic-analysis-used-electric-vehicle-batteriesintegrated-commercial-building-microgrids/

4. Neubauer, J.; Pesaran, A. "The ability of battery second use strategies to impact plug-in electric vehicle prices and serve utility energy storage applications." Journal of Power Sources 2011, 196, (23), 10351-10358. http://

www.sciencedirect.com/science/article/pii/ $\underline{\text { S0378775311012377 }}$

5. Williams, B. D.; Lipman, T. E. Analysis of the Combined Vehicle- and Post-Vehicle-Use Value of Lithium-Ion Plug-In-
Vehicle Propulsion Batteries; report number TBD (in press); California Energy Commission: Sacramento CA, 2011.

6. Smith, K.; Markel, T.; Kim, G.-H.; Pesaran, A., Design of Electric Drive Vehicle Batteries for Long Life and Low Cost. In IEEE Accelerated Stress Testing and Reliability Workshop, Denver, CO, 2010.

7. ESRL, "Average Mean Temperature Index by month." http://www.esrl.noaa.gov/psd/data/usclimate/tmp.state. 19712000.climo

8. Traffic Choices Study - Summary Report; Puget Sound Regional Council: April, 2008. http://psrc.org/assets/37/ summaryreport.pdf

9. Dinger, A.; Martin, R.; Mosquet, X.; Rabi, M.; Rizoulis, D.; Russo, M.; Sticher, G. Batteries for Electric Cars:

Challenges, Opportunities, and the Outlook to 2020; Boston Consulting Group: 2010. http://www.bcg.com/documents/ file36615.pdf

10. Hensley, R.; Knupfer, S.; Pinner, D. Electrifying cars: How three industries will evolve; McKinsey \& Company: 2009.

11. Lache, R.; Galves, D.; Nolan, P. Vehicle Electrification: More rapid growth; steeper price declines for batteries; Deutsche Bank: 2010.

12. Howell, D., "Annual Merit Review: Energy Storage R\&D and ARRA Overview." 2010. http:// www1.eere.energy.gov/vehiclesandfuels/pdfs/ merit_review 2010/electrochemical_storage/ es00a howell_2010_o.pdf

13. AUTONOMIE Cost Model; Ricardo, U.S. Department of Energy: 24 Nov, 2010. http://www.autonomie.net

14. O'Keefe, M.; Brooker, A.; Johnson, C.; Mendelsohn, M.; Neubauer, J.; Pesaran, A. In Battery Ownership Model: A Tool for Evaluating the Economics of Electrified Vehicles and Related Infrastructure, 25th International Battery, Hybrid and Fuel Cell Electric Vehicle Symposium \& Exposition, Shenzhen, China, 5 - 9 November, 2010; Shenzhen, China, 2010. http://www.nrel.gov/docs/fy11osti/49127.pdf

15. "National and State Corporate Income Tax Rates, U.S. States and OECD Countries, 2011." The Tax Foundation. 2011. http://www.taxfoundation.org/taxdata/show/ 23034.html

16. Narula, C. K.; Martinez, R.; Onar, O.; Starke, M. R.; Andrews, G. Economic Analysis of Deploying Used Batteries in Power Systems; Oak Ridge National Laboratory: Oak Ridge, TN, 2011.

17. Electricity Energy Storage Technology Options: A White Paper Primer on Applications, Costs and Benefits; 1020676; Electric Power Research Institute (EPRI): Palo Alto, CA, Dec, 2010.

18. Eyer, J.; Corey, G. Energy Storage for the Electricity Grid: Benefits and Market Potential Assessment Guide; 
SAND2010-0815; Sandia National Laboratories: Feb, 2010.

http://prod.sandia.gov/techlib/access-control.cgi/

$\underline{\text { 2010/100815.pdf }}$

19. "Schedule TOU-GS-3-SOP Time-of-Use - General Service - Super Off-Peak - Demand Metered." Southern California Edison. http://www.sce.com/NR/sc3/tm2/pdf/ ce282.pdf

The Engineering Meetings Board has approved this paper for publication. It has successfully completed SAE's peer review process under the supervision of the session organizer. This process requires a minimum of three (3) reviews by industry experts. ISSN 0148-7191
Positions and opinions advanced in this paper are those of the author(s) and not necessarily those of SAE. The author is solely responsible for the content of the paper.

SAE Customer Service:

Tel: 877-606-7323 (inside USA and Canada)

Tel: 724-776-4970 (outside USA)

Fax: 724-776-0790

Email: CustomerService@sae.org

SAE Web Address: http://www.sae.org

Printed in USA 